\title{
25 Research Soure \\ Development of Cantaloupe (Cucumis melo) Lines Carrying Vat Gene with Favorable Fruit Traits
}

\author{
Parisa Jariani \\ University of Tehran \\ Hossein Ramshini \\ University of Tehran \\ Mahmoud Lotfi ( $\nabla$ mlotfi@ut.ac.ir) \\ Fatemeh Amini \\ University of Tehran \\ Hassan Abtahi \\ University of Tehran \\ Rahim Ahmadvand \\ Seed and Plant Improvement Research Institute
}

University of Tehran https://orcid.org/0000-0003-2961-2898

\section{Research Article}

Keywords: Heritability, marker-assisted selection, melon breeding, virus aphid transmission, virus-resistant

Posted Date: April 7th, 2021

DOI: https://doi.org/10.21203/rs.3.rs-396387/v1

License: (c) (i) This work is licensed under a Creative Commons Attribution 4.0 International License. Read Full License 


\section{Abstract}

The most popular Iranian cantaloupe 'Samsoori' is highly susceptible to devastating viruses transmitted by Aphis gossypii. A dominant gene (Vat) causing resistance to the aphid and viruses was detected in 'Ginsen Makuwa' in spite of its low fruit quality. They were crossed and the segregating offspring were assessed for combining favorable traits with Vat gene. In the $F_{2}$ population, moderate to high broad-sense heritability estimates were found for measured traits including, fruit weight (0.78) and soluble solid content (SSC) (0.7). The $F_{3}$ families were significantly different from each other for earliness, fruit shape indices, cavity, flesh thickness, SSC, and fruit numbers per plant. Resistant and susceptible plants were determined by genotyping 210 plants in $\mathrm{F}_{4}$ generation using a dominant DNA marker for the resistant allele of Vat gene. Out of 15 selected $\mathrm{F}_{3}$ families, four were susceptible, three were homozygote resistant and six showed segregation in their progeny for the Vat gene. Selection assisted by Vat gene marker was a very useful and applied approach for the identification of healthy plants along with phenotypic selection.

\section{Introduction}

Melon (Cucumis melo L.; Cucurbitaceae; $2 n=2 x=24$ ), is a cross-pollinated horticultural crop with a wide diversity in fruit shape, flavor traits, and climate adaptation. Iran is an important center of variation and also rank in the top five production countries in the world for melons (FAO 2019). Many high-quality cantaloupe landraces or indigenous cultivars are cultivated in large acreages in Iran due to their unique flavor and shape and early concentrated fruiting. Despite consumer preference for local cultivars, the majority of them are susceptible to biotic stresses such as fungal and viral diseases, which cause annual colossal yield loss. Thus, in recent years, a number of farmers prefer to pay for commercial hybrid seeds provided by seed companies to assure healthier plants with higher yields.

Viral diseases are the most devastating diseases of melons, which cause a severe damage to the fruit and lower its yield and quality. The most prevalent viruses in melons are cucurbit aphid borne yellow virus (CABYV), cucumber mosaic virus (CMV), cucurbit yellow stunting disorder virus (CYSDV), zucchini yellow mosaic virus (ZYMV), papaya ringspot virus (PRSV), and watermelon mosaic virus (WMV). The most effective approach to control viral diseases is by developing resistant cultivars (Prohens-Tomás and Nuez 2008). There is a line of research describing the virus resistance in melon. A breeding line derived from PI 414723 with resistance to three potyviruses (WMV, ZYMV, PRSV) and powdery mildew. All four resistances displayed dominant monogenic inheritance and a genetic linkage was observed between resistance to WMV and ZYMV (Anagnostou et al. 2000). It was displayed that the resistance to CMV is oligogenic, where different loci confer resistance to different CMV strains, but not necessarily quantitative (Essafi et al. 2009). Diaz et al. (2011) constructed an integrated genetic map associated with economically important traits in melon including four virus resistance genes.

Furthermore aphids are also important pests that harm crops either directly through the feeding of the phloem texture or indirectly through the transmission of viral diseases ( $\mathrm{Ng} \&$ Perry, 2004). Most plant viral infections can be partially controlled by elimination of their vectors; however, this is not a recommended method due to environmental concerns by pesticide application. Therefore, the use of resistant cultivars is the best approach for controlling aphids and whiteflies. The only aphid species that can colonize effectively on melon is Aphis gossypii which is the vector of CMV, ZYMV, PRSV, and WMV (Dogimont et al., 2014). By means of a RIL population developed from a cross between Vedrantais and PI161375, two minor QTLs were found for resistance to biotype B of Bemisia tabaci, and a major dominant gene (Vat) for resistance to Aphis gossypii (Boissot et al., 2010). It was shown that the virus aphid transmission (Vat) gene is located on linkage group 5, and confers double resistance to Aphis gossypii as well as the viruses transmitted by it. The amino acid sequences of this gene for resistance and susceptible alleles were well characterized, and the DNA sequence of the resistance allele was determined (Dogimont et al., 2014). 
The availability of suitable molecular markers encourages plant breeders to use them for marker-assisted selection and speed up the breeding process (Sousaraei et al., 2018). This method can overcome the limitations associated with phenotypic selection (Foolad \& Panthee, 2012), especially for virus resistance that phenotypic selection is often not straight forward or costly; the use of molecular markers can be a very beneficial tool.

Cultivar 'Samsoori' is the main commercial cantaloupe cultivar in Iran. It is well-known for its early concentrated fruiting, striped and fine netted rind, and desirable juicy flavor. However, this cultivar is highly susceptible to viruses and its sugar content is not satisfactory. In a breeding program, 'Samsoori' for improvement was crossed with the Korean melon 'Ginsen Makuwa' which shows high resistance to viruses and has high sugar content. The main objective of this study was to identify the offspring in a $F_{3}$ generation of a cross between 'Samsoori' and 'Ginsen Makuwa' carrying Vat resistant allele (Boissot et al., 2016) with desirable traits such as high soluble solid content (SSC), proper shape and fruit flavor, early harvest, and high yield. However, initially it was necessary to clarify the efficiency of the molecular marker to distinguish the resistant and susceptible allele of Vat gene in the segregating population.

\section{Materials And Methods Plant material}

The melon genotypes used in this study were 'Samsoori', 'Ginsen Makuwa', and the derivative progenies of their cross. The fruit of 'Samsoori' is round to oblate with leathery rind and a clear vein tract and thorough netting. It has full slip from its vine once ripe, and its flesh is juicy green. In contrast, the fruit of 'Ginsen Makuwa' is oval shape with a very thin rind and a ridged surface, no netting and yellowish-white color. The flesh of fruit is crunchy texture and white color (Fig. 1).

For crossing Samsoori was used as the pistillate and Ginsen Makuwa as the staminate parent, here thereafter referred to as $P_{1}$ and $P_{2}$, respectively. The initial cross was made in the spring of 2017, at the greenhouse of Auraihan campus,

Pakdasht, Iran. Ten seeds were germinated and grew to maturity and self-pollinated to create the $F_{2}$ population $(n=350)$. In the spring of 2018 , each parent's seed, $F_{1} s$, and $F_{2} s$ were sown in potting trays. Within a month after sowing the seed, the plants were hardened off and transplanted to the field, in a randomized complete block design experiment in three replications. Each block consisted of one row (10 seedlings) of $\mathrm{P} 1, \mathrm{P} 2$, and $\mathrm{F}_{1}$ and five rows of $\mathrm{F}_{2}$ generation. During the flowering time, each plant in the $F_{2}$ generation was self-pollinated. Thus, on the day of anthesis, male flowers of the same plant were used for pollinating androgynous flowers, which both were covered in the previous evening.

\section{Phenotypic Evaluation of P1, P2, F1 and F2 generations}

At the end of the growth season, matured fruits were harvested. Earliness of fruits was recorded as the number of days from the date of transplanting of seedlings to the field until the harvest date. Fruit yield in each plant was calculated with summing up the weight of all fruits from each plant. Other traits such as fruit length, width, flesh thickness, and seed cavity were measured for each fruit after longitudinal cutting. Soluble solid content (SSC) was measured using a handheld Refractometer (Master-20PM, Atago, Japan) from fruit juice extracted by squeezing a piece from the middle of each fruit.

\section{Phenotypic selection of desirable plants in F2}

During the growth season, the healthy plants of $F_{2}$ population were labeled. Disease free plants with early mature fruit, high SCC (brix index), acceptable fruit shape (round shape with thorough netting and clear vein tracts), desirable flesh features (green, juicy and thick) were selected within the $F_{2}$ population. Out of 150 plants in the $F_{2}$ population, 20 were selected. Since each plant had at least one fruit developed from self-pollinattion, they produced 20 different $F_{3}$ families. Phenotypic evaluation of F3 families 
In spring 2019 the seedling of $20 \mathrm{~F}_{3}$ families as well as parental genotypes (in total 22 treatments) were evaluated for different traits in the experimental station of Aburaihan campus, Pakdasht, Iran. The seedlings were transplanted in randomized complete block design with three replications. Each plot consisted of a row with ten plants. Important traits were measured the same way as the previous generation, and during flowering time, all $F_{3}$ plants were self-pollinated to produce $\mathrm{F}_{4}$ generation. Based on the collected data, a total of top rated 70 plants were selected within and between rows of $F_{3}$ families. Subsequently, three seeds of each selected $F_{4}$ plant were sown in the greenhouse to maturity, and their leaf tissue was used for DNA extraction and genotyping.

\section{Parental and Cultivar Survey for the Vat gene}

It was necessary to verify the reliability and efficiency of the molecular marker before applying it for selection of resistant plants in $F_{4}$ families. Thus, six Iranian native cultivars and 11 other genotypes (Table 1), were clarified for the presence or absence of the Vat gene. Then $\mathrm{F}_{4}$ families were tested by extracting DNA from all three plants of 70 families beside 'Ginsen Makuwa', 'Samsoori' and F1 generation as genetic controls.

Table 1

Name and characters of genotypes tested for the presence or absence of the Vat gene.

\begin{tabular}{|lll|}
\hline Name of genotype & type & Supplied from \\
\hline Samsoori & Local cultivar & Varamin - Iran \\
\hline Saveh & Local cultivar & Savezh - Iran \\
\hline Shah-abadi & Local cultivar & Isfahan - Iran \\
\hline Rish-baba & Local cultivar & Kashan - Iran \\
\hline Garmak & Local cultivar & Isfahan - Iran \\
\hline Tile-torogh & Local cultivar & Mashhad - Iran \\
\hline Cory (Galia) & Commercial hybrid & Seminis Co. \\
\hline Kogane 9-go Makuwa & Oriental accession & IPK genebank \\
\hline Kanro Kiku Makuwa & Oriental accession & IPK genebank \\
\hline Ginsen Makuwa & Oriental accession & IPK genebank \\
\hline Kogane Sennari Makuwa & Oriental accession & IPK genebank \\
\hline Charentais Fom-1 & Breeding line & donated by M. Pitrat \\
\hline Charentais Fom-2 & Breeding line & donated by M. Pitrat \\
\hline Isabelle & Breeding line & donated by M. Pitrat \\
\hline Ananasi & Commercial cultivar & Market \\
\hline Crenshaw & Commercial cultivar & Market \\
\hline Honey Dew & Commercial cultivar & Market \\
\hline
\end{tabular}

DNA was extracted from leaves of each genotype by CTAB method (Doyle \& Doyle, 1990). A pair of specific primers (forward primer 5' CCTCAGTTCTTCAACATTTGATTTCTC 3' and reverse primer 5' CCATCACATTTATAAACCCGAAGATG 3') 
were used for amplifying a part of the resistant allele of Vat gene (Dogimont et al., 2014). The PCR product of this primer pair is $121 \mathrm{bp}$, and no amplification is expected for the susceptible allele. The PCR reaction was carried out by LightCycler ${ }^{\circledR} 96$ Real-Time PCR machine (Roche Diagnostics, Mannheim, Germany). HiFi master mix with Hot Start Taq polymerase enzyme (Custombiotech, Roche) was used for PCR reaction. The $20 \mu$ reaction contained $2 \mu$ l of template DNA $(30 \mathrm{ng} / \mu \mathrm{l}), 4 \mu \mathrm{l}$ of HiFi Master-mix (5X), and $1 \mu \mathrm{l}$ of each primer $(10 \mu \mathrm{M})$. The amplification condition comprised preincubation $\left(15 \mathrm{~min}\right.$ at $95^{\circ} \mathrm{C}$ ) for activation of Taq polymerase enzyme, followed by 40 cycles of $95^{\circ} \mathrm{C}$ for $15 \mathrm{~s}, 61^{\circ} \mathrm{C}$ for $20 \mathrm{~s}$, and $72^{\circ}$ for $20 \mathrm{~s}$. To test the specificity of PCR, the melting curve of PCR products were obtained and compared to each other. Gel electrophoresis of PCR products was conducted on $2 \%$ agarose gel containing TAE at $100 \mathrm{~V}$ for $2 \mathrm{~h}$. The safe stain was used for staining of DNA. Amplified bands were visualized under ultraviolet light.

\section{Data analysis}

The analysis of variance of phenotypic data was carried out using SAS software version 9.0 (Cary, NC). Outlier data points were detected by visually inspecting the scattered plots or using any data point with larger two standard deviations from the mean, and were removed from the dataset for further analyses. Comparison of the means of different treatments was carried out using the Duncan's Multiple Range test.

The following equation was used for calculating broad-sense heritability in $F_{2}$ population (Brown et al., 2014).

$$
\mathrm{H}_{\mathrm{b}}=\frac{\mathrm{Vg}}{\mathrm{V}_{\mathrm{F} 2}}
$$

Where $H_{b}$ is broad-sense heritability, $V_{F 2}$ is the phenotypic variance of $F_{2}$ population. $V g$ was calculated with the following formula:

$$
\mathrm{V}_{\mathrm{g}}=\mathrm{V}_{\mathrm{F} 2}-\frac{\mathrm{V}_{\mathrm{P} 1}+\mathrm{V}_{\mathrm{P} 2}+2 \mathrm{~V}_{\mathrm{F} 1}}{4}
$$

\section{Results And Discussion \\ Phenotypic evaluation of P1, P2, F1, and F2}

Analysis of variance among different generations showed significant differences for most traits. Table 2 shows the mean comparison of different generations for measured traits. There are significant differences for all traits except yield that was not significantly different among different generations. Substantial diversity for different traits was expected as the parents belonged to different groups; 'Samsoori' is fit to cantalupensis while 'Ginsen Makuwa' is an oriental melon belonging to conomon cultivar group (Pitrat, 2017). The phenotypic characteristics of $F_{1}$ progeny were intermediated (Fig. 1) and in $F_{2}$ progeny were segregating between parents. 
Table 2

Mean comparison of different generations for the measured traits as well as the minimum and maximum values of the $\mathrm{F}_{2}$ plants and broad sense heritability.

\begin{tabular}{|c|c|c|c|c|c|c|c|}
\hline \multirow[b]{2}{*}{ Traits } & \multirow[b]{2}{*}{$P_{1}$} & \multicolumn{3}{|c|}{ Generation } & \multirow{2}{*}{$\begin{array}{l}\text { Minimum } \\
\text { in } F_{2}\end{array}$} & \multirow{2}{*}{$\begin{array}{l}\text { Maximum } \\
\text { in } \mathrm{F}_{2}\end{array}$} & \multirow{2}{*}{$\begin{array}{l}\text { Broad Sense } \\
\text { Heritability }\end{array}$} \\
\hline & & $P_{2}$ & $F_{1}$ & $F_{2}$ & & & \\
\hline Fruit number per plant & $2.06 c$ & $5.66 a$ & $3.01 b c$ & $4.05 b$ & 1 & 12 & 0.57 \\
\hline Yield (kg/plant) & $1.33 a$ & $1.37 a$ & $1.56 a$ & $1.7 \mathrm{a}$ & 0.21 & 4.81 & 0.7 \\
\hline Fruit weight (kg) & $0.72 a$ & $0.23 c$ & $0.52 \mathrm{ab}$ & $0.45 b$ & 0.14 & 1.67 & 0.78 \\
\hline Earliness (days) & $99.2 \mathrm{bc}$ & $104.3 a$ & $97.4 \mathrm{c}$ & $101.4 \mathrm{ab}$ & 87 & 121 & 0.80 \\
\hline Fruit length (mm) & $131 a$ & $104 b$ & $128 a$ & $122 a$ & 77 & 208 & 0.71 \\
\hline Fruit width (mm) & $112 a$ & $80 c$ & $108 a b$ & $100 \mathrm{~b}$ & 64 & 176 & 0.73 \\
\hline SSC\% & $10.2 c$ & $12.2 b$ & $14.6 a$ & $12.3 b$ & 7 & 18.3 & 0.70 \\
\hline Flesh thickness (cm) & $2.3 a$ & $1.4 d$ & $1.9 \mathrm{bc}$ & $1.8 \mathrm{c}$ & 1.1 & 3.4 & 0.64 \\
\hline Cavity width (cm) & $6.8 a$ & $4.2 \mathrm{c}$ & $5.7 \mathrm{~b}$ & $5.3 b$ & 3.4 & 9.5 & 0.64 \\
\hline \multicolumn{8}{|c|}{$\begin{array}{l}\mathrm{P}_{1} \text { : 'Samsoori', } \mathrm{P}_{2} \text { : 'Ginsen Makuwa', Earliness: Days from transplanting to harvest, SSC (\%): soluble solid content. } \\
\text { Means with different superscript letters are significantly different from each other according to Duncan multiple range } \\
\text { test }(\mathrm{p} \leq 0.01) \text {. }\end{array}$} \\
\hline
\end{tabular}

Moderate to high values for broad-sense heritability for most traits show that this population has the potential for improvement via genetic selection. For most traits in the $F_{2}$ population, transgressive segregation was observed, as the range of data in $F_{2}$ population is broader than the difference between parents. This result may be explained by the fact that parental genotypes are genetically distantly related from each other.

As an index for sweetness between two parents, a significant difference was observed for soluble solid content (SCC\%). A wide range in $\mathrm{F}_{2}$ population for this trait provides an opportunity for the selection of genotypes with higher sugar content. Low sugar content in Iranian landraces was reported before (Pouyesh et al., 2017); therefore 'Ginsen Makuwa' with high sugar content in addition to its virus resistance appears to be a right complementary parent for improvement of 'Samsoori'.

Although the disease severity index could not be measured in the field accurately, but the difference of the parents for the level of incidence and segregating of the trait among offsprings was quite obvious.

\section{Evaluation of traits in F3 generations}

Analysis of variance (ANOVA) revealed highly significant differences among treatments for all measured traits (Table 3). In order to select the best families, means of different traits was compared among 22 treatments. Table 4 illustrates the characteristics of different $F_{3}$ families, along with parental genotypes. The number of fruits per plant in 'Samsoori' was on average 2.5 while for 'Ginsen Makuwa' it was 8.1. Fruit weight of 'Samsoori' was higher than that of 'Ginsen Makuwa'. In $\mathrm{F}_{3}$ families, a wide range was observed for these two traits. Also, there are two families that are significantly had higher SSC than that of 'Samsoori' which means selection for this trait has been led an increase in the sweetness of progenies. The response to selection was more evident for fruit shape (round or oval, netting and vein tract), flesh color, and texture. In Table 5 the genotypes were categorized based on fruit-related traits. The flesh color, vein tract, netting, and flesh texture 
are differentiated by nominal scale, and the shape index is the ratio of fruit length to width. Considerably the frequency of desirable plant type (round fruit with netting and vein tract, juicy green flesh) in most families is higher than unfavorable ones. The length to width ratio for all families is near 1 in contrast to this ratio for 'Ginsen Makuwa', which is 1.37. These findings confirm the idea that netting skin, vein tract, flesh color, and fruit shape are controlled with oligo-genes with high heritability (Dogimont, 2011).

Table 3

Mean squares of ANOVA for different traits measured in 22 treatments $\left(20 F_{3}\right.$ families along with $P_{1}$ 'Samsoori' and $P_{2}$ 'Ginsen Makuwa' as controls). The experiment was conducted as a randomized complete block design with three replications.

\begin{tabular}{|c|c|c|c|c|c|c|c|c|c|c|}
\hline S.O.V. & df & Earliness & $\begin{array}{l}\text { Fruit } \\
\text { weight }\end{array}$ & $\begin{array}{l}\text { Fruit } \\
\text { length }\end{array}$ & $\begin{array}{l}\text { Fruit } \\
\text { width }\end{array}$ & Cavity & $\begin{array}{l}\text { Flesh } \\
\text { thickness }\end{array}$ & SSC & Yield & $\begin{array}{l}\text { No. of } \\
\text { fruits per } \\
\text { plant }\end{array}$ \\
\hline Replication & 2 & 31.08 & $36090 *$ & $2.46^{\star}$ & $2.50 \star *$ & $0.77^{\star *}$ & 0.021 & $3.00 * *$ & $4.87^{\star \star}$ & $7.9 * *$ \\
\hline Treatments & 21 & $21.13^{\star}$ & $77831^{\star \star}$ & 2.76 *夫 & $3.32 \star \star$ & $1.03^{\star \star}$ & $0.19 * \star$ & $4.00 * \star$ & 0.542 & $4.7^{\star \star}$ \\
\hline Error & 42 & 10.45 & 10076 & 0.60 & 0.44 & 0.15 & 0.056 & 0.36 & 0.495 & 1.11 \\
\hline C.V. (\%) & & 3.16 & 14.6 & 6.9 & 6 & 6.6 & 8.8 & 6.07 & 29 & 29 \\
\hline
\end{tabular}


Table 4

Means of parents (P1: 'Samsoori', P2: 'Ginsen Makuwa') and F3 families measured for different traits.

\begin{tabular}{|c|c|c|c|c|c|c|c|c|c|}
\hline $\begin{array}{l}\text { Parents } \\
\text { and } \\
\text { F3 } \\
\text { families }\end{array}$ & Earliness & $\begin{array}{l}\text { Fruit } \\
\text { Weight (g) }\end{array}$ & $\begin{array}{l}\text { Fruit } \\
\text { Length } \\
\text { (cm) }\end{array}$ & $\begin{array}{l}\text { Fruit } \\
\text { Width } \\
\text { (cm) }\end{array}$ & $\begin{array}{l}\text { Cavity } \\
\text { (cm) }\end{array}$ & $\begin{array}{l}\text { Flesh } \\
\text { thickness } \\
\text { (cm) }\end{array}$ & SCC \% & $\begin{array}{l}\text { Yield } \\
(\mathrm{kg} / \mathrm{p})\end{array}$ & $\begin{array}{l}\text { No. of } \\
\text { fruits } \\
\text { per } \\
\text { plant }\end{array}$ \\
\hline $\mathrm{P} 1$ & $101.26^{\mathrm{ab}}$ & $1012.50^{a}$ & $11.32^{\mathrm{abc}}$ & $12.98^{a}$ & $6.81^{\mathrm{ab}}$ & $3.18^{a}$ & $9.40^{\mathrm{C}}$ & $2.7 a$ & $2.5 \mathrm{~cd}$ \\
\hline P2 & $103.75^{\mathrm{ab}}$ & $353.68^{\mathrm{g}}$ & $11.58^{\mathrm{abc}}$ & $8.41^{\mathrm{g}}$ & $4.25^{\mathrm{g}}$ & $2.11^{\mathrm{e}}$ & $14.02^{\mathrm{a}}$ & $2.9 a$ & $8.1 \mathrm{a}$ \\
\hline B4101 & $96.97^{b}$ & $448.13^{f g}$ & $9.47^{d}$ & $9.17^{\mathrm{ij}}$ & $4.82^{f g}$ & $2.51^{\text {cde }}$ & $10.16^{c}$ & $1.9 a$ & 4.3bcd \\
\hline B682 & $106.62^{\mathrm{a}}$ & $938.21^{a b}$ & $12.65^{\mathrm{a}}$ & $12.52^{\mathrm{ab}}$ & $6.38^{a b c}$ & $3.01^{\mathrm{ab}}$ & $8.88^{c}$ & $2.45 a$ & $2.6 \mathrm{~cd}$ \\
\hline B692 & $102.79^{a b}$ & $940.74^{a b}$ & $11.34^{\mathrm{abc}}$ & $12.41^{a b c}$ & $6.52^{\mathrm{ab}}$ & $2.84^{\mathrm{abc}}$ & $9.86^{c}$ & $2.6 a$ & $2.7 \mathrm{~cd}$ \\
\hline B133 & $104.57^{a b}$ & $706.96^{\text {cde }}$ & $10.75^{\mathrm{bcd}}$ & $11.13^{\text {cdefg }}$ & $6.27^{\mathrm{abcd}}$ & $2.47^{\text {cde }}$ & $10.83^{b}$ & $2.01 \mathrm{a}$ & $2.8 \mathrm{~cd}$ \\
\hline B872 & $103.19^{a b}$ & $606.60^{\text {def }}$ & $10.70^{\mathrm{bcd}}$ & $10.61^{\mathrm{fgh}}$ & $5.66^{\text {bcdef }}$ & $2.59^{\mathrm{bcd}}$ & $8.85^{c}$ & $2.15 \mathrm{a}$ & $3.5 \mathrm{bcd}$ \\
\hline BT13102 & $99.40^{a b}$ & $540.45^{\text {defg }}$ & $10.41^{\mathrm{cd}}$ & 10.19ghi & $5.21^{\mathrm{ef}}$ & $2.65^{\mathrm{bcd}}$ & $11.92^{b}$ & $1.9 a$ & $3.4 \mathrm{bcd}$ \\
\hline B13103 & $102.11^{\mathrm{ab}}$ & $843.66^{a b c}$ & $12.57^{a}$ & $11.74^{\text {abcdef }}$ & $6.09^{a b c d e}$ & $2.87^{\mathrm{abc}}$ & $10.30^{c}$ & $2.7 a$ & $3.2 \mathrm{bcd}$ \\
\hline B242 & $104.23^{a b}$ & $940.23^{a b}$ & $12.00^{a b}$ & $12.04^{\mathrm{abcde}}$ & $5.67^{\text {bcdef }}$ & $3.18^{a}$ & $8.88^{c}$ & 3.3a & 3.7bcd \\
\hline BT521 & $98.79^{a b}$ & $617.03^{\text {def }}$ & $10.72^{\mathrm{bcd}}$ & $10.79^{\text {efgh }}$ & $5.80^{\text {bcde }}$ & $2.46^{\text {cde }}$ & $9.62^{c}$ & $2.05 a$ & $3.4 \mathrm{bcd}$ \\
\hline BT732 & $100.49^{a b}$ & $655.32^{\text {cdef }}$ & $10.29^{\mathrm{cd}}$ & $10.82^{\text {defgh }}$ & $5.41^{\text {def }}$ & $2.74^{\mathrm{abc}}$ & $9.92^{c}$ & $1.8 \mathrm{a}$ & $2.7 \mathrm{~cd}$ \\
\hline B172 & $100.03^{a b}$ & $738.54^{\text {bcde }}$ & $11.24^{\mathrm{abc}}$ & $11.35^{\text {bcdefg }}$ & $6.32^{\mathrm{abcd}}$ & $2.57^{\text {bcde }}$ & $9.36^{c}$ & $2.4 a$ & 3.3bcd \\
\hline B971 & $104.81^{a b}$ & $526.92^{\mathrm{efg}}$ & $9.69^{d}$ & $10.43^{f g h}$ & $5.83^{\text {bcde }}$ & $2.48^{\text {cde }}$ & $9.81^{c}$ & $1.9 a$ & $3.6 \mathrm{bcd}$ \\
\hline BT743 & $105.50^{\mathrm{ab}}$ & $767.88^{\mathrm{bcd}}$ & $11.65^{\mathrm{abc}}$ & $12.03^{\mathrm{abcde}}$ & $6.19^{\mathrm{abcd}}$ & $2.89^{a b c}$ & $9.06^{c}$ & $2.5 a$ & $3.3 b c d$ \\
\hline B592 & $98.90^{a b}$ & $564.64^{\text {defg }}$ & $9.67^{d}$ & $10.57^{f g h}$ & $5.73^{\text {bcde }}$ & $2.54^{\text {bcde }}$ & $9.66^{c}$ & $1.9 a$ & $3.4 \mathrm{bcd}$ \\
\hline B123 & $103.54^{\mathrm{ab}}$ & $745.59^{\text {bcde }}$ & $12.66^{\mathrm{a}}$ & $11.48^{\text {bcdefg }}$ & $5.93^{\text {abcde }}$ & $2.77^{a b c}$ & $9.09^{c}$ & $2.1 \mathrm{a}$ & $2.7 \mathrm{~cd}$ \\
\hline B1192 & $100.54^{a b}$ & $719.72^{\text {bcde }}$ & $11.61^{\mathrm{abc}}$ & $11.40^{\text {bcdefg }}$ & $5.86^{\text {bcde }}$ & $2.81^{a b c}$ & $9.46^{c}$ & $2.3 a$ & $3.2 \mathrm{bcd}$ \\
\hline B1482 & $100.43^{a b}$ & $853.69^{a b c}$ & $11.76^{\mathrm{abc}}$ & $12.15^{\mathrm{abcd}}$ & $7.20^{a}$ & $2.81^{a b c}$ & $8.75^{c}$ & $2.04 \mathrm{a}$ & $2.2 d$ \\
\hline B392 & $105.43^{a b}$ & $667.76^{\text {cdef }}$ & $11.79^{a b c}$ & $10.93^{\text {defgh }}$ & $5.86^{\text {bcde }}$ & $2.59^{\mathrm{bcd}}$ & $9.51^{\mathrm{c}}$ & $2.5 a$ & 3.7bcd \\
\hline B721 & $98.09^{a b}$ & $462.36^{f g}$ & $9.62^{d}$ & $9.72^{\mathrm{hi}}$ & $5.51^{\text {cdef }}$ & $2.19^{\text {de }}$ & $10.31^{c}$ & $2.8 a$ & $5.7 b$ \\
\hline B251 & $103.21^{\mathrm{ab}}$ & $634.21^{\mathrm{cdef}}$ & $10.88^{b c d}$ & $10.63^{f g h}$ & $5.68^{\text {bcdef }}$ & $2.57^{\text {bcde }}$ & $10^{c}$ & $3.5 a$ & $5.4 \mathrm{bc}$ \\
\hline
\end{tabular}


Table 5

Classification of F3 families considering fruit related traits. Data for flesh color, vein tract, netting and flesh texture are the frequencies of their nominal scale (percentage of all fruits measured in each treatment). Also, the shape index is the ratio of fruit length to width calculated based on data from Table 4.

\begin{tabular}{|c|c|c|c|c|c|c|c|c|c|}
\hline \multirow[t]{2}{*}{ Parents and F3 Families } & \multicolumn{2}{|c|}{ Flesh color } & \multicolumn{2}{|c|}{ Vein tract } & \multicolumn{2}{|c|}{ Netting } & \multicolumn{2}{|c|}{ Flesh texture } & \multirow[t]{2}{*}{ Shape index } \\
\hline & Green & Others $^{a}$ & Yes & No & Yes & No & Juicy & others & \\
\hline $\mathrm{P} 1$ & 100 & 0 & 100 & 0 & 100 & 0 & 100 & 0 & 0.87 \\
\hline $\mathrm{P} 2$ & 0 & 100 & 0 & 100 & 0 & 100 & 0 & 100 & 1.38 \\
\hline B4101 & 83 & 17 & 90 & 10 & 52 & 48 & 97 & 3 & 1.03 \\
\hline B682 & 100 & 0 & 98 & 2 & 95 & 5 & 88 & 12 & 1.01 \\
\hline B692 & 88 & 12 & 100 & 0 & 66 & 34 & 92 & 8 & 0.91 \\
\hline B133 & 94 & 6 & 100 & 0 & 95 & 5 & 87 & 13 & 0.96 \\
\hline B872 & 100 & 0 & 96 & 4 & 74 & 26 & 93 & 7 & 1 \\
\hline BT13102 & 47 & 53 & 89 & 11 & 46 & 54 & 91 & 9 & 1.02 \\
\hline B13103 & 90 & 10 & 96 & 4 & 44 & 56 & 91 & 9 & 1.07 \\
\hline B242 & 68 & 32 & 89 & 11 & 73 & 27 & 81 & 19 & 0.99 \\
\hline BT521 & 53 & 47 & 97 & 3 & 73 & 27 & 95 & 5 & 0.99 \\
\hline BT732 & 91 & 9 & 99 & 1 & 82 & 18 & 82 & 18 & 0.95 \\
\hline B172 & 100 & 0 & 98 & 2 & 85 & 15 & 91 & 9 & 0.99 \\
\hline B971 & 100 & 0 & 98 & 2 & 88 & 12 & 85 & 15 & 0.92 \\
\hline BT743 & 58 & 42 & 85 & 15 & 77 & 23 & 94 & 6 & 0.96 \\
\hline B592 & 26 & 76 & 93 & 7 & 79 & 21 & 97 & 3 & 0.91 \\
\hline B123 & 47 & 53 & 98 & 2 & 78 & 22 & 91 & 9 & 1.10 \\
\hline B1192 & 65 & 35 & 99 & 1 & 84 & 16 & 87 & 13 & 1.01 \\
\hline B1482 & 85 & 15 & 100 & 0 & 79 & 21 & 87 & 13 & 0.96 \\
\hline B392 & 75 & 25 & 97 & 3 & 96 & 4 & 80 & 20 & 1.07 \\
\hline B721 & 34 & 66 & 95 & 5 & 49 & 51 & 96 & 4 & 0.98 \\
\hline B251 & 96 & 4 & 85 & 15 & 90 & 10 & 95 & 5 & 1.02 \\
\hline
\end{tabular}

\section{Genotyping of Vat gene in different populations Screening of different genotypes}


The specific primer pair developed by Dogimont et al. (2014) for the resistant allele of Vat produced $121 \mathrm{bp}$ fragment. Figure 2 depicts the amplification curve of this primer pair with Real time PCR for different genotypes. HRM analysis showed the unique DNA fragment had been amplified only in 'Ginsen Makuwa' and "Karno Kiku Makuwa" among 17 tested genotypes (see material and methods). None of other genotypes include Iranian cultivars showed amplification curve and hence they had no resistant allele of Vat. These results is in congruity with the findings of a previous study in which 'Ginsen Makuwa' displayed double resistance toward A. gossypii and CMV (Boissot et al., 2016).

\section{Marker assisted selection of resistant plants in $\mathrm{F}_{4}$ populations}

Figure 3 shows the melting peak of amplified fragment in control parental genotypes in which the melting peak of resistant allele in 'Ginsen Makuwa' and $F_{1}$ generation are clearly different from primer dimer peaks in 'Samsoori'. This experiment was carried out several times to screen the $F_{4}$ population. After amplification, the melting curve was obtained for all samples in a plate (Fig. 4). For some plants there were only the resistant allele of Vat while for others no amplification was observed or a minor primer-dimer peak was observed. Figure 5 shows the electrophoresis of PCR product of the primer for control parental genotypes and some F4 generation plants.

In total 178 plants were genotyped in $\mathrm{F}_{4}$ generation. Table 6 shows the results of classification of plants as resistant and susceptible in each family of $F_{3}$. If the original selected plant in $F_{2}$ generation was homozygote then all descended $F_{4}$ plants are expected to be homozygote and whether the selected plant in $F_{2}$ was heterozygote, plants in $F_{4}$ generation will be diverse according to Mendelian single gene segregation. Out of $13 F_{3}$ families, six showed segregation regarding the Vat gene. Hence, they have been descended from a heterozygote plant in F2 plant. The ratio of resistant and susceptible plants descended from these plants corresponded the expected ratio of $9 / 16$ for resistant and $7 / 16$ for susceptible plants on the basis of Chi square test. 
Table 6

Genotyping of plants in F4 generation for Vat gene. It revealed three F2 plants were homozygote resistant, four plants were susceptible and six plants were heterozygote.

\begin{tabular}{|c|c|c|c|c|c|}
\hline Row & $\begin{array}{l}\text { Selected } \\
F_{2} \text { plant } \\
\text { (or } F_{3} \\
\text { family) }\end{array}$ & $\begin{array}{l}\text { No. of resistant } \\
\text { Plants in } \mathrm{F}_{4} \\
\text { generation }\end{array}$ & $\begin{array}{l}\text { No. of } \\
\text { Susceptible plants in } \mathrm{F}_{4} \text { generation }\end{array}$ & $\begin{array}{l}X^{2} \text { statistic for } \\
\text { fitting Mendelian } \\
\text { ratio }\end{array}$ & $\begin{array}{l}\text { Deduced } F_{2} \\
\text { genotype of the } \\
\text { selected plant }\end{array}$ \\
\hline 1 & BT 743 & 7 & 0 & - & Vat Vat \\
\hline 2 & B872 & 13 & 0 & - & Vat Vat \\
\hline 3 & B172 & 41 & 0 & - & Vat Vat \\
\hline 4 & B1192 & 0 & 15 & - & vat vat \\
\hline 5 & B971 & 0 & 16 & - & vat vat \\
\hline 6 & B682 & 0 & 13 & - & vat vat \\
\hline 7 & B13103 & 0 & 4 & - & vat vat \\
\hline 8 & BT 732 & 4 & 4 & $0.13 \mathrm{~ns}$ & Vat vat \\
\hline 9 & B392 & 9 & 3 & $1.71 \mathrm{~ns}$ & Vat vat \\
\hline 10 & B251 & 13 & 9 & $0.07 n s$ & Vat vat \\
\hline 11 & B133 & 14 & 4 & $3.39 \mathrm{~ns}$ & Vat vat \\
\hline 12 & BT 13102 & 4 & 2 & $0.26 \mathrm{~ns}$ & Vat vat \\
\hline 13 & BT 521 & 1 & 2 & $0.64 \mathrm{~ns}$ & Vat vat \\
\hline
\end{tabular}

\section{Conclusion}

The current research made a major contribution to marker assisted selection for aphid and virus resistance in melon. The marker related to Vat gene was easy, fast and reliable enough to be substituted phenotypic selection. Also, it costs less because evaluating of virus resistance in plants via artificial inoculation is complicated and time-consuming, though by marker selection large number of plantlets could be screened in a short time.

The study also was an advancement in breeding of Iranian cantaloupe landraces with valued characters for virus resistance and improving sweetness. Further characterization of $F_{5}$ families (lines) is necessary for developing and selection of best lines which can be introduced as new cultivars or be included in commercial hybrid production.

\section{Declarations}

\section{Funding -}

The project was funded by Iran National Science Foundation (INSF grant number: 93/S/36998)

\section{Conflict of interest -}

The authors declared that they have no conflicts of interest that could have appeared to influence the work reported in this paper. 


\section{Availability of data and material -}

The authors confirm that the data supporting the findings of this study are available within the article and any supporting data could be requested from the correspond author, ML; but the developed lines are restricted by funder.

\section{Code availability -}

Not applicable.

\section{Author contributions-}

$\mathrm{ML}$ and $\mathrm{HR}$ were involved in planning and supervised the work, PJ and HA contributed in collecting the data, RA supported lab experiments, FA performed statistical analysis, ML and HR processed the experimental data and wrote the paper with input from all authors.

\section{ACKNOWLEDGMENTS -}

The authors are grateful to Iran National Science Foundation for funding this research project (INSF grant number: 93/S/36998). The authors also would like to extend their gratitude to Dr. Hamid Ashrafi at NC State University for reviewing the manuscript and his constructive comments.

\section{References}

1. Anagnostou K, Jahn M, Perl-Treves R (2000) Inheritance and linkage analysis of resistance to zucchini yellow mosaic virus, watermelon mosaic virus, papaya ringspot virus and powdery mildew in melon. Euphytica 116:265270. https://doi.org/10.1023/A:1004005716806

2. Boissot N, Schoeny A, Vanlerberghe-Masutti $F$ (2016) Vat, an amazing gene conferring resistance to aphids and viruses they carry: from molecular structure to field effects. Front Plant Sci 7:1420. https://doi.org/10.3389/fpls.2016.01420

3. Boissot N, Thomas S, Sauvion N, Marchal C, Pavis C, Dogimont C (2010) Mapping and validation of QTLs for resistance to aphids and whiteflies in melon. Theor Appl Genet 121:9-20. https://doi.org/10.1007/s00122-010-12878

4. Brown J, Caligari PS, Campos HA (2014) Plant Breeding. JohnWiley\& Sons Ltd

5. Diaz A, Fergany M, Formisano $G$ et al (2011) A consensus linkage map for molecular markers and quantitative trait loci associated with economically important traits in melon (Cucumis melo L.). BMC Plant Biol 11:1-14. https://doi.org/10.1186/1471-2229-11-111

6. Dogimont C (2011) 2011 gene list for melon. Rep Cucurbit Genet Coop 133:104-133.

7. Dogimont C, Chovelon V, Pauquet J, Boualem A, Bendahmane A (2014) The Vat locus encodes for a CC-NBS-LRR protein that confers resistance to Aphis gossypii infestation and A. gossypii-mediated virus resistance. Plant $\mathrm{J}$ 80:993-1004. https://doi.org/10.1111/tpj.12690

8. Doyle JJ, Doyle JL (1990) Isolation of plant DNA from fresh tissue. Focus 12(13):39-40.

9. Essafi A, Díaz-Pendón JA, Moriones E, Monforte AJ, Garcia-Mas J, Martín-Hernández AM (2009) Dissection of the oligogenic resistance to Cucumber mosaic virus in the melon accession PI 161375. Theor appl genet 118:275-284. https://doi.org/10.1007/s00122-008-0897-x

10. FAOSTAT (2019) Food and Agricultural Organization of the United Nations. http://www.fao.org/faostat/en/\#rankings/countries_by_commodity 
11. Foolad MR, Panthee DR (2012) Marker-assisted selection in tomato breeding. CRC Crit Rev Plant Sci 31:93-123. https://doi.org/10.1080/07352689.2011.616057

12. Ng JC, Perry KL (2004) Transmission of plant viruses by aphid vectors. Mol Plant Pathol 5:505-511. https://doi.org/10.1111/j.1364-3703.2004.00240.x

13. Pitrat M (2017) Melon genetic resources: phenotypic diversity and horticultural taxonomy. In: Grumet R et al. (eds) Genetics and genomics of Cucurbitaceae. Springer, pp 25-60.

14. Pouyesh A, Lotfi M, Ramshini H, Karami E, Shamsitabar A, Armiyoun E (2017) Genetic analysis of yield and fruit traits in cantaloupe cultivars. Plant Breed 136:569-577. https://doi.org/10.1111/pbr.12486

15. Prohens-Tomás J, Nuez F (Eds) (2007) Vegetables I: Asteraceae, Brassicaceae, Chenopodicaceae, and Cucurbitaceae. Springer-Verlag, New York

16. Sousaraei N, Ramshini H, Lotfi M, Sharzei A (2018) Marker assisted backcrossing for introgression of Fusarium wilt resistance gene into melon. Euphytica 214:7. https://doi.org/10.1007/s10681-017-2080-4

\section{Figures}
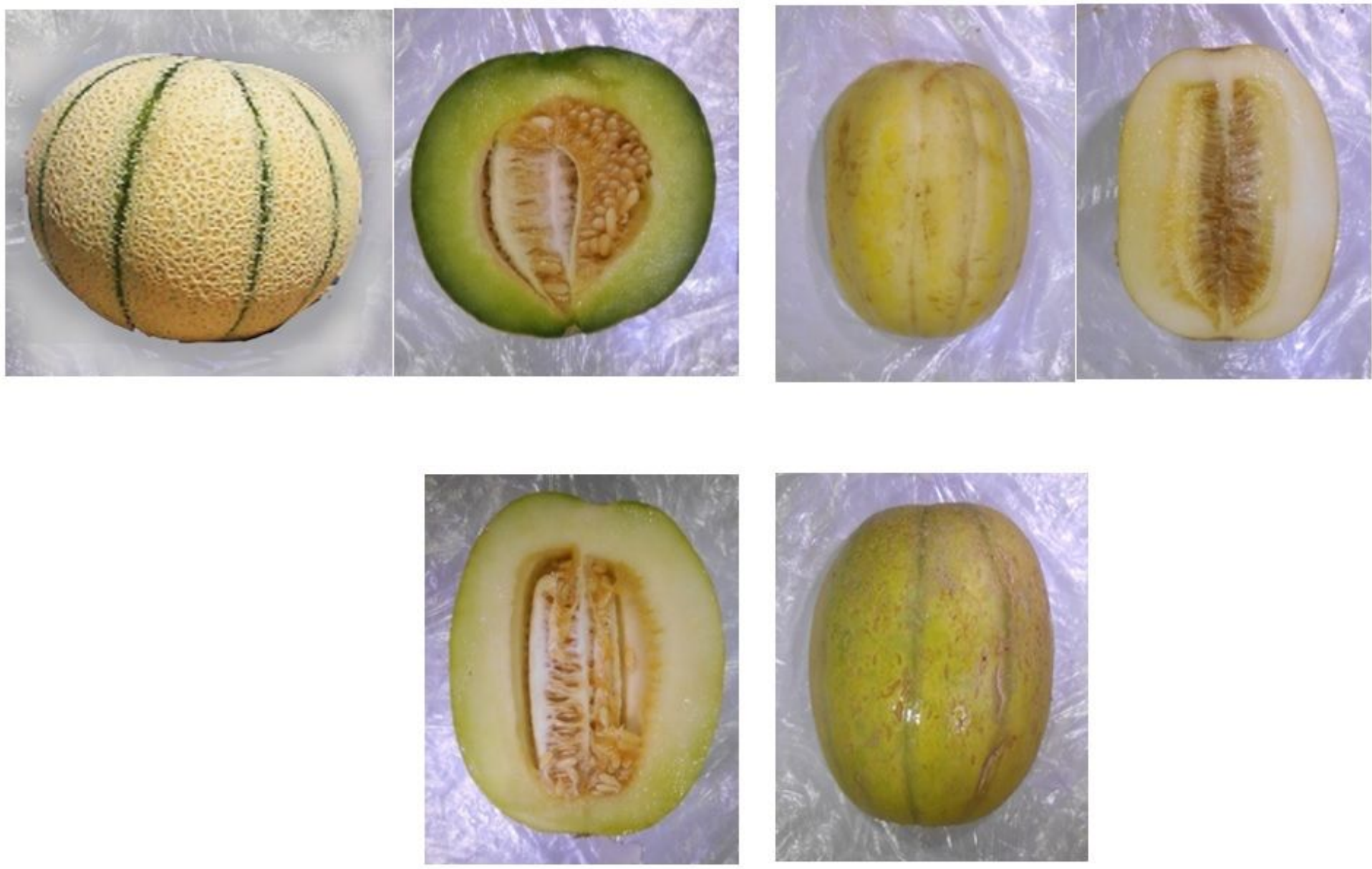

\section{Figure 1}

Fruit shape of 'Samsoori' (P1, top left), 'Ginsen Makuwa' (P2, top right), and their F1 generation (bottom). 


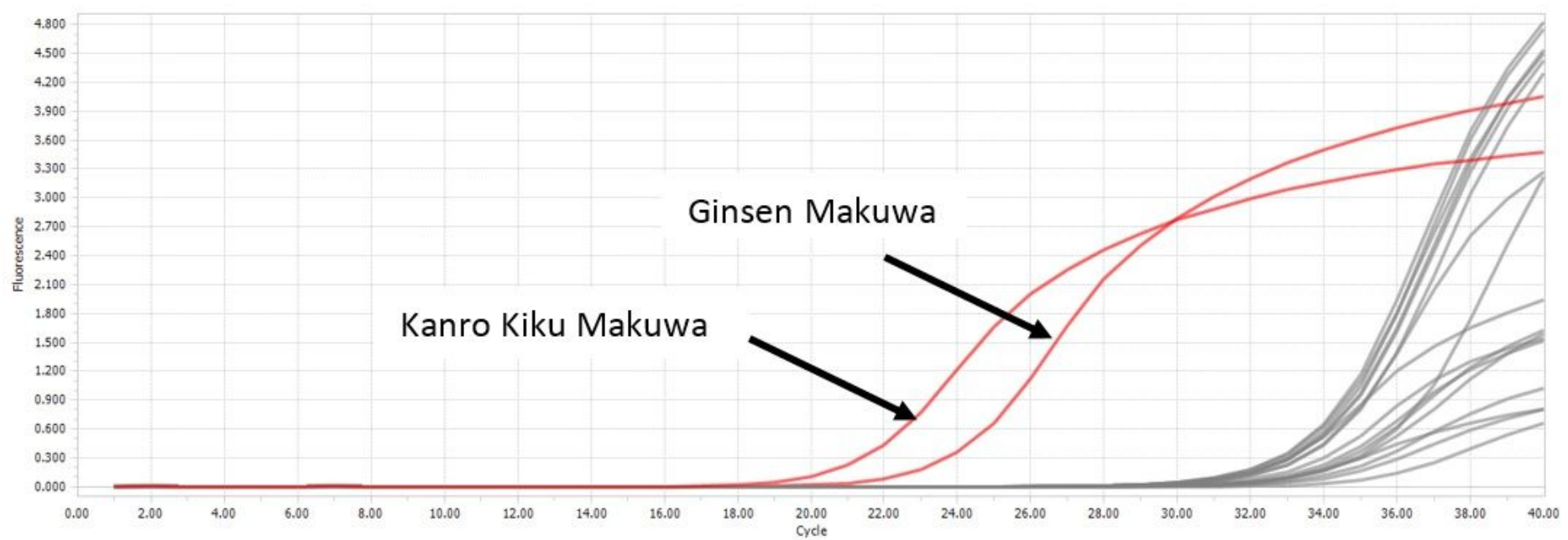

Figure 2

Amplification curve in Real time PCR for a part of resistant allele of the Vat gene. The primer pair sequence used for PCR was according to a previous study (Dogimont et al. 2014). All amplification curves after cycle 33 are primer dimers (see Figure4 and 5)

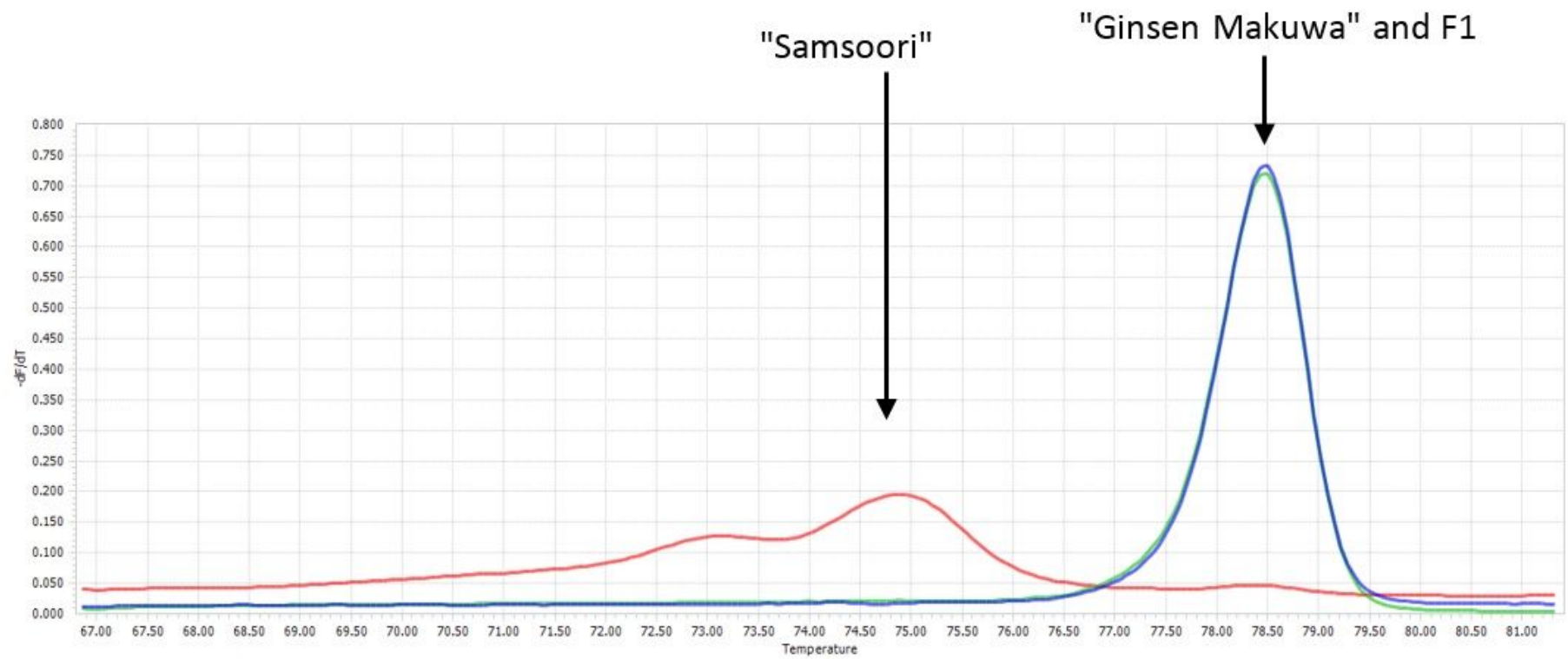

Figure 3

Melting curves of amplified PCR products with the primer pair specific to resistant allele of Vat in control parental genotypes of 'Ginsen Makuwa' (blue color), 'Samsoori' (red color) and F1 (green color). The electrophoresis of PCR product showed that the peak related to 'Samsoori' is primer dimers. 


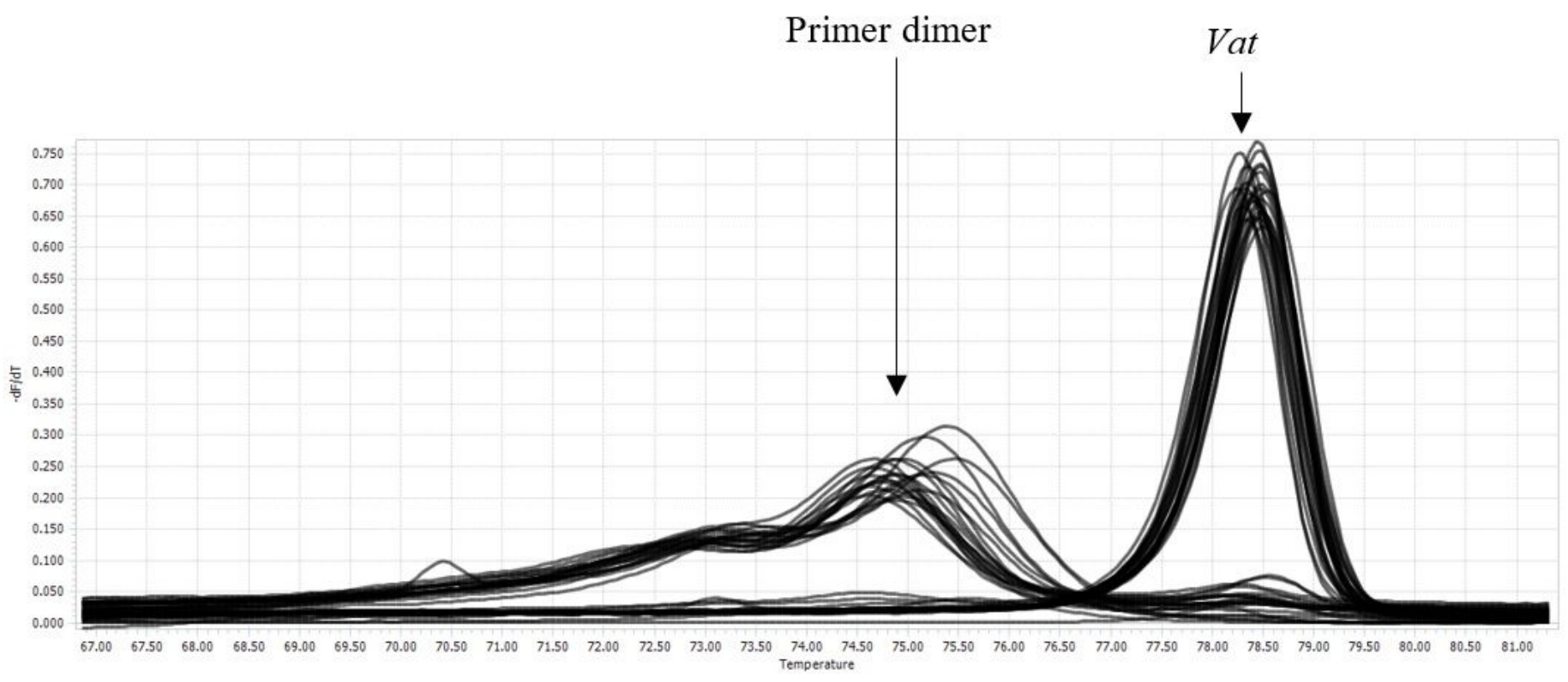

\section{Figure 4}

Melting curve of amplified PCR products with the primer pair specific to resistant allele of Vat in F4 generation plants. In all amplification experiments 'Samsoori', 'Ginsen Makuwa' and F1 were included. In all experiments, in each plate (96 well), three wells were assigned for non-DNA template controls.

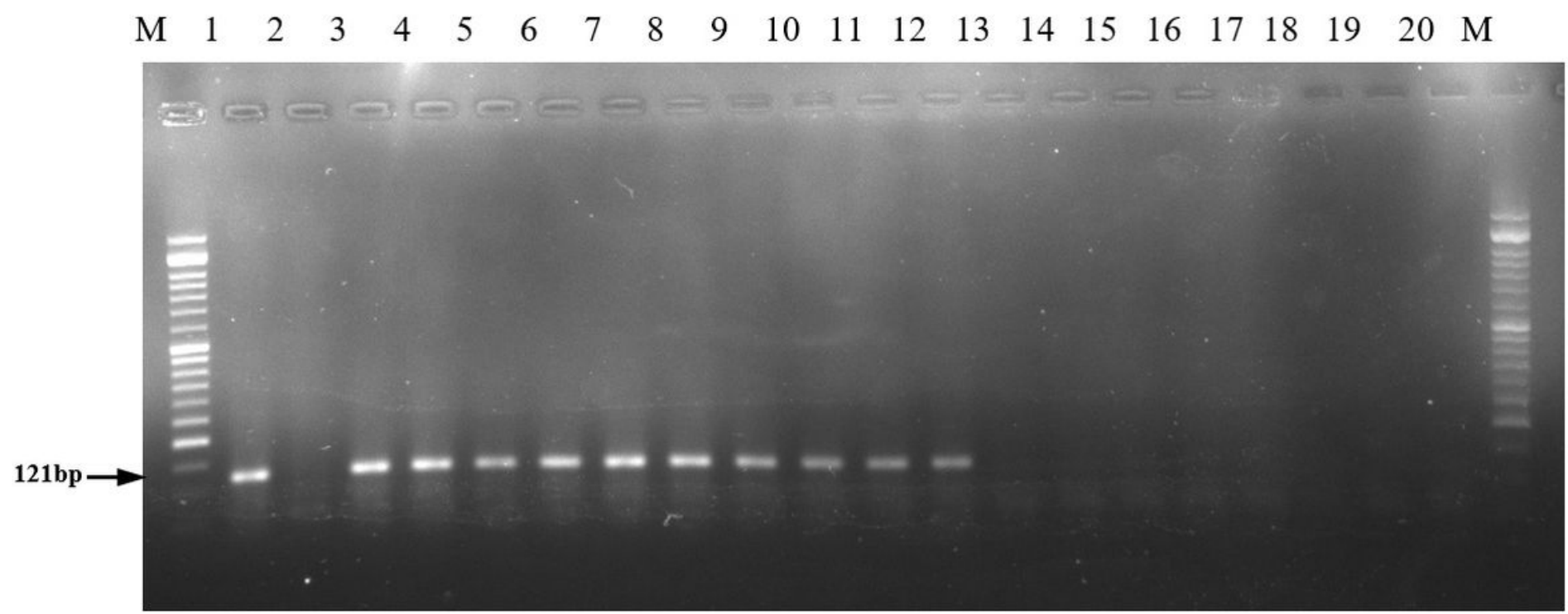

\section{Figure 5}

Gel electrophoresis of amplified fragment of resistant allele of Vat. M: size marker, 1: 'Ginsen Makuwa', 2: 'Samsoori', 3: F1, 4-12: different plants in F4 population which are carrying resistant allele of Vat, 13-18: different plants in F4 population which are carrying susceptible allele of Vat, 19-20: non-template DNA controls. 